\title{
İzmir'de ikinci ve üçüncü basamak sağlık kuruluşlarına başvuran gebelerin aile hekimi tarafından izlenme sıklıkları ve etkileyen etmenler
}

\author{
Raika Durusoya, Aslı Davasa, Işıl Ergina, Hür Hassoya, Feride Aksu Tanıka
}

\begin{abstract}
Özet
Amaç: İzmir'de ikinci ve üçüncü basamak sağlık kuruluşlarına başvuran gebelerin aile hekimi (AH) tarafından tespit ve izlem sıklıklarını ve bunları etkileyen etmenleri değerlendirmek. Yöntem: Tanımlayıcı olan bu araştırma için, Aralık 2008 - Şubat 2009 tarihleri arasında İzmir'de bir ikinci, bir üçüncü basamak hastaneye izlem ya da doğum için başvuran 580 kadınla görüşülmüştür. Sosyodemografik özellikler, gebelikteki ilk izlem zamanları, AH'ne kayıt ve izlem durumu, 27 sorudan oluşan bir anketle sorgulanmıştır. Analizlerde ki-kare, McNemar ve t-testi kullanılmıştır. Bulgular: Araştırmaya katılan 580 gebenin 397'siyle (\%64) ikinci basamak, 183'üyle (\%32) üçüncü basamak hastanede görüşüldü. Kadınların \%55'i ilkokul ve altı eğitim düzeyine sahipti, \%28'ini yeşil kartı olanlar veya sağlık güvencesi olmayanlar oluşturmaktaydı. Kadınların 307'si (\%53) ilk çocuğuna hamileydi ve yaş ortalamaları 27.1ะ5.5 idi. Gebelerin \%26'sı gebelik testini aile sağlığ merkezinde yaptırmıştı ve ilk kontrolleri için en sık başvurdukları yerler sırasıyla devlet hastanesi (\%33) ve aile hekimidir (\%27). Gebelerin \%14'ünün AH'lerini bilmediği, \%10'unun AH'de gebe kaydının bulunmadığı ve \%15'inin AH tarafından izlenmediği saptanmıştır. Gebeler ortalama $11.3 \pm 6.3 \mathrm{kez}$ izlenmişlerdir, bunun $4.3 \pm 3.3$ 'ü aile sağlı̆̆ biriminde gerçekleşmiştir. AH tarafından izlenen gebelerin \%95'i AH'ne kendisi başvurmuştu. Gebelerin ancak \%69'u zamanında tespit edilmişti, \%49'unu sadece ebeler izlemekteydi ve sadece \%3'üne ev ziyareti yapılmış, \%77'si telefonla kuruma çağrılmıştır. Son iki yılda İzmir'e göçle gelen, okuryazar olmayan, yükseköğrenim mezunu olan, çalışan, emekli sandığı mensubu olan, yüksek gelir düzeyine sahip olan gebelerin aile hekimleri tarafından izlenme oranları daha düşüktür. Sonuç: Gebelerin \%10'unun kayıtlı olmaması ve \%15'inin izlenmemesi düşündürücüdür. Gebe izlemlerine aile hekimlerinin katılımı arttırılmalıdır. Birinci basamağın daha etkin rol almasını sağlayacak müdahalelere ihtiyaç bulunmaktadır.
\end{abstract}

Anahtar Sözcükler: Gebe izlemi, gebe tespiti, doğum öncesi bakım, aile hekimliği, birinci basamak sağlık hizmeti

\section{Prenatal care utilization from family physicians: a study among pregnant women applying to secondary and tertiary care hospitals in Izmir}

\begin{abstract}
Aim: To evaluate the registration and follow-up rates of pregnant women by family physicians (FP) and factors influencing these rates.

a Uzm. Dr., Ege Üniversitesi Tıp Fakültesi Halk Sağlı̆̆ı AD,İzmir

a Öğr. Gör., Ege Üniversitesi Tıp Fakültesi Halk Sağlığı AD,İzmir

a Öğr.Gör., Ege Üniversitesi Tıp Fakültesi Halk Sağlığı AD,İzmir

a Uzm. Dr., Ege Üniversitesi Tıp Fakültesi Halk Sağlığı AD,İzmir

a Prof.Dr., Ege Üniversitesi Tıp Fakültesi Halk Sağlığı AD,İzmir

Sorumlu Yazar: Raika Durusoy, Ege Üniversitesi Tıp Fakültesi Halk Sağlığı AD. İzmir, E-posta: raikadurusoy@ege.edu.tr
\end{abstract}


Method: For this descriptive survey, pregnant women applying to one secondary and one tertiary care hospital in Izmir for antenatal care or delivery between December 2008-February 2009 were interviewed. Socio-demographic characteristics, the timing of their first antenatal visit, their registration with and follow-up status of their FP were surveyed with a questionnaire including 27 questions. Chi-square, Mc Nemar's and t-tests were used for analyses. Results: Among the 580 participants, 397 (64\%) were interviewed in secondary and $183(32 \%)$ in tertiary care hospitals. Among the women, $55 \%$ had primary school or a lower educational level, $28 \%$ were green card holders or did not have any social security. Among participants, 307 (53\%) were going to have their first child and their mean age was $27.1 \pm 5.5$. $26 \%$ had their pregnancy test in a family practice centre. Women mostly made their first antenatal visit to state hospitals (33\%) or their FPs (27\%). 14\% of the women did not know their FP, $10 \%$ were not registered with their FP and 15\% did not receive antenatal care from their FP. The pregnant women had a mean of $11.3 \pm 6.3$ antenatal visits, $4.3 \pm 3.3$ of them with their FPs. $95 \%$ of the women who were followed-up by their FP had applied to their FP themselves. Only 69\% were recorded on time. $49 \%$ were being followed-up only by their midwife. Only $3 \%$ were visited at home by their midwives and $77 \%$ were called by the phone and invited to the FP's centre. Women who have migrated to Izmir in the past two years, illiterate women, women with university-degrees, working women, women having the social security of state employees, and with a high income had lower rates of follow-up by FPs. Conclusion: The $10 \%$ lack of registration and 15\% lack of follow-up among pregnant women is challenging. The participation of FPs in antenatal care should be increased. Interventions are required to ensure a more effective role of primary care in prenatal care.

Key Words: Antenatal care, pregnancy follow-up, family medicine, primary health service

\section{Giriș}

Dünyada her gün yaklaşı 1000 kadın gebelik ve doğuma bağlı sorunlar nedeniyle kaybedilmektedir. Bu ölümlerin $\% 99$ 'u gelişmekte olan ülkelerde gerçekleşmektedir ve büyük çoğunluğunu önlenebilir ölümler oluşturmaktadır. Doğum öncesi bakım (DÖB) bu ölümlerin önlenmesindeki en önemli araçlardan

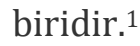

DÖB'nin temel amacl, annelerin sağlıklı bir gebelik geçirmelerini, sağlıklı bebeklerin doğmasını sağlamaktır. Gebelerin ilk üç ayda en az bir kez görülmeleri, gebelik süresince eğitimli sağlık personeli tarafından izlenmeleri, sağlıklı ve güvenli bir gebelik geçirilmesi ve olası risk etmenlerinin erken belirlenmesi özellikle az gelişmiş ülkelerde gebe kadınlarda görülen aneminin tanınması ve sağaltımı- açısından önemlidir.

Türkiye Nüfus ve Sağlık Araştırması 2008 (TNSA 2008) verilerine göre Türkiye'de dört ve üzerinde doğum öncesi bakım alan kadın oranı kentte \%80 ve kırda \%55'dir. Gebelerin \%25'i beşinci ve ay ve sonrasında tespit edilmektedir. ${ }^{2}$

Doğum öncesi bakım hizmetleri, birinci basamak sağlık hizmetleri açısından öncelikli ve özel bir yere sahiptir. Gebeliğin birinci basamakta izlenmesi; gebe ve bebeğin, bağışıklama, uygun eğitimlerin verilmesi, riskin erken dönemde saptanması gibi tüm koruyucu hizmetlere erişimini arttırır ve istenmeyen sonuçların sıklığını azaltır. Birinci basamakta izlem, erişimin hem ulaşım, hem ekonomik nedenlerle daha kolay olması nedeniyle hizmette sürekliliği arttırır. İskoçya'da gebelikte birinci basamakta genel pratisyen ve ebe izlemiyle kadın doğum uzmanlarının izlemlerinin etkinliğinin araştırıldığı bir çalışmada, düşük riskli gebelerin uzmana başvurusunun ne klinik ne de kullanıcı memnuniyeti açısından bir fark yaratmadığı ortaya konmuştur. ${ }^{3}$

Doğum öncesi bakımın sayı ve niteliğini, bu dönemde sağlık personeli tarafından yapılan ev ziyaretlerinin 
arttırdığı literatürde gösterilmiştir. Erken doğum ve düşük doğum ağırlığına olumlu etkileri de tartışılmaktadır. ${ }^{4}$ Ev ziyaretleri anne sütünün daha uzun süre verilmesini sağlamakta, bebek ve annenin ruh sağlığını geliştirmektedir. ${ }^{5}$ Özellikle gelişmekte olan ülkelerde kimi anneler için ev ziyaretleri doğum öncesi bakımın verildiği tek nokta olabilmektedir. Sağlık Bakanlığı'nın yürüttüğü "sağlıkta dönüşüm" programının ana unsurlarından biri aile hekimliğidir. Aile hekimliği uygulaması İzmir'de 14.05.2007 tarihinde fiilen başlatılmıştır. ${ }^{6}$ Ardından uygulama ülkeye giderek yaygınlaştırılmıştır ve 2011 itibariyle tüm illerde aile hekimliği uygulamasına geçilmiştir. Türkiye'de birinci basamak sağlık hizmetlerinin nasıl örgütlenip sunulacağına dair ilke ve kuralları içeren ve 1961 yllında kabul edilmiş bulunan 224 sayılı "Sağlı Hizmetlerinin Sosyalleştirilmesi Hakkındaki Kanun" da, tüm ülkede aile hekimliğine geçişle birlikte yürürlükten tamamen kaldırılmıştır. Aile hekimliği sisteminde, doğum öncesi izlem açısından aile hekimine yasa ile verilmiş yetki ve görevler; doğum öncesi izlem yapmak, kişiye yönelik rehberlik, sağlığ geliştirici ve koruyucu hizmetler ile anaçocuk sağlığı hizmetlerini vermek, sunduğu hizmetlere ilişkin sağlık kayıtlarını tutmak, gerekli bildirimleri yapmak ve kendisine kayıtlı kişilerin sağlık durumlarını ev ziyareti ile tespit etmektir. Aile sağlığ elemanı için ise doğum öncesi bakım başlığ altında değerlendirilebilecek yasal yükümlülükleri gezici hizmetler, sağlı̆̆ geliştirici sağlık eğitimi, koruyucu hizmetler ile ana-çocuk sağlı̆̆ı ve aile planlaması hizmetleri olarak bildirilmektedir. ${ }^{7}$

Aile hekimlerinin yürütmekle yükümlü olduğu aşı takibi, gebe takibi ve çocuk-bebek takibi hizmetleri aile hekimliği sisteminde performans değerlendirmesi kapsamında ele alınmış ve tüm bu uygulamaların gereği gibi yerine getirilmemesi durumlarında yapılacak kesintiler pilot kanunda belirtilmiştir. Sözleşme veya görevlendirmeyle çalıştırılan aile sağlığı elemanları için de geçerli olan bu oranlar, hesaplanan brüt ücretin; aylık başarı oranı $\% 90-95$ ise $\% 1$ 'i, $\% 80-90$ ise \%2'si, \%80'den daha düșük ise \%5'inin kesilmesi şeklinde belirlenmiştir. Zorunlu gebe izlem sayıları bu modelde azaltılarak dörde indirilmekle birlikte, \%80'in altına düşmesi, aile hekiminin sözleşme fesih nedenlerinden biri olarak kabul edilmiștir. ${ }^{8}$

Türkiye'de 1988-2008 yılları karşılaştırıldığında kadınların son beş yıl içinde gerçekleșen son doğumlarında sağlık personelinden (doktor ve hemşire/ebe) en az bir kez DÖB almış olma oranı \% 43'den \% 92'ye yükselmiştir. Ancak hizmet kullanımında ve sunumunda bölgeler ve yerleșim yerleri arasında farklılıklar devam etmektedir.2,9 DÖB hizmetine erişimin kolaylaştırılması, tespitin ve izlem yeterliliğinin nicel ve nitel olarak iyileștirilmesi anne ve çocuk sağlığ hizmetleri açsından hayati önem taşımaktadır. ${ }^{10}$ Oysa aile hekimliğine geçişle birlikte izlem sayıları azaltılmıştır ve gebe tespitleri için önemli bir araç olan ev ziyaretlerinin günlük pratikte pek uygulanmamaktadır. Ayrıca aile hekimliği, liste temelli olduğu için özellikle yeni göç edenlerin hiçbir aile hekiminin listesine kayıtlı olmama olasılığı bulunmaktadır.

Aile hekimliğinde gebe tespitlerinin ne düzeyde yapılabildiği, izlemlerin yeterliliğiyle ilgili yapılmış saha çalışması henüz bulunmamaktadır. $\mathrm{Bu}$ konuda araştırma izni de verilmemektedir. $\mathrm{Bu}$ araştırmanın amacl, İzmir'de ikinci ve üçüncü basamak sağlık kuruluşlarına başvuran gebelerin ve doğum yapmış olan kadınların; aile hekimine kayıtlılık oranlarını, aile hekimi tarafından izlenme oranlarını, aile hekimi ile ilk temas zamanlarını ve nedenlerini, aile hekimi izlemi kapsamında olmayı etkileyen etmenleri belirlemektir.

\section{Yöntem}

Tanımlayıcl olan bu araștırma, İzmir'de aile hekimliğine geçildikten 1.5 yll sonra gerçekleştirildi. İkinci basamağı temsilen İzmir Ekrem Hayri Üstündağ Kadın Hastalıkları ve Doğum Hastanesi (Konak Doğumevi) ve üçüncü basamağı temsilen Ege Üniversitesi Tıp Fakültesi Kadın Hastalıkları ve Doğum Anabilim Dalı seçildi ve iki kurumun yönetiminden araştırma için 
izin alındı. Aralık 2008 - Şubat 2009 tarihleri arasında bu kurumlara izlem ya da doğum için başvuran 617 kadın araştırmaya katıldı. İkinci basamak hastaneye Aralık 2008'de 7 ardışık iş günü ziyaret gerçekleștirildi. Üçüncü basamak hastane de Şubat 2009 'da 15 iş günü ziyaret edildi. Her iki hastanede de bu tarihlerde gebe izlem polikliniğine başvuran bütün gebelerle ve yine aynı tarihte serviste yatmakta olan yeni doğum yapmış tüm kadınlarla görüşülerek bu tarihlerde kurumda bulunan ve hedef grubunda yer alan tüm kadınlarla görüşüldü. İzmir ili dışında yaşayanlar çalışma kapsamı dışında tutularak analize 580 kiși dahil edildi.

Sosyodemografik özellikler, gebelikteki izlem kaynakları, aile hekimine kayıt ve izlem durumuyla ilgili değişkenler, 27 sorudan oluşan bir anketle ölçüldü. Tetanoz bağışıklama durumları, beyana dayalı olarak, gereğinde de aşı kartı incelenerek değerlendirildi. Sağlı ocağ dönemiyle karşılaştırmak açısından, başka çocuğu olanlara bir önceki gebeliklerinde sağlık ocağı tarafından izlenip izlenmedikleri, ebenin eve ziyarete gelip gelmediği ve o dönemde İzmir'de oturup oturmadıkları soruldu. Anketler kurumların gebe izlem polikliniklerinin bekleme salonlarında ve doğum servislerinde kadınlarla yüzyüze görüşerek uygulandı.

Gebelik nedeniyle aile hekimine kendiliğinden başvuranların oranı çok yüksek olduğu için, bunun nedenlerini daha ayrintılı sorgulayan bir soru anket uygulamasının üçüncü gününden itibaren eklendi. Benzer şekilde tetanoz bağışıklama durumu sorgulanırken gebelik öncesi yapılmış aşıların da dikkate alınabilmesi için bir soru daha eklendi. Sonradan eklenen ve çalışmanın temel bağımlı veya bağımsız değişkenlerini oluşturmayan bu sorularda veri eksikliği görece fazla olmuștur.
Kadınlara hanelerinin toplam aylık geliri ve hanede yaşayan toplam kişi sayısı soruldu. $\mathrm{Bu}$ iki değerin birbirine bölünmesiyle kişi başına düşen aylık gelir hesaplandl.

Gebelerin gestasyon haftalarına göre aile hekimliğinde izlenme durumları değerlendirilirken aile sağlığı merkezi tarafından yapılan toplam izlem sayıları, gebelik haftaları itibariyle toplam izlenmeleri gereken sayı ile karşılaştırıldı. Analizlerde ki-kare, McNemar, t-testi ve Kruskal-Wallis varyans analizi kullanıldı.

\section{Bulgular}

Araştırmaya katılan kadınların genel demografik özellikleri Tablo 1'de ayrıntılı olarak sunulmaktadır.

Araştırmaya katılan 580 gebenin 397'siyle (\%68.4) ikinci basamak, 183'üyle (\%31.6) üçüncü basamak hastanede görüşüldü. Görüşmelerin 438'i (\%76.4) gebe izlem polikliniğinde, 135 'i (\%23.6) doğum sonrası yataklı serviste gerçekleştirildi. Gebelerin 514'ü (\%88.8) İzmir'in metropol ilçelerinde yaşamaktaydı. Kadınların 307'si (\%53.0) ilk çocuğuna hamileydi veya doğurmuştu. $\mathrm{Bu}$ üç değişken dişındaki sosyodemografik ve gebelikleriyle ilgili özellikleri, görüşmenin yapıldığı kuruma göre fark göstermekteydi (Tablo 1).

Kadınların aile hekimini sağlık ocağından ne kadar farklı alglladığının dolaylı bir göstergesi olarak birinci basamağı tanımlarken kullandıkları terim işaretlendi. $\mathrm{Bu}$ işaretlemenin yapıldığı 334 kadının 281'i (\%84.1) hala "sağlık ocağı" terimini kullanırken 46'sı (\%13.8) "aile hekimi" terimini kullanıyordu. Kadınların gebelik testi, ilk izlem yeri, aile hekimi tarafından gebeliğin tespiti ve izlenme oranlarıyla ilgili özellikleri, Tablo 2'de özetlenmektedir. 
Tablo 1. Araştırmaya katılan kadınların sosyodemografik özellikleri ve gebelikleriyle ilgili özellikleri

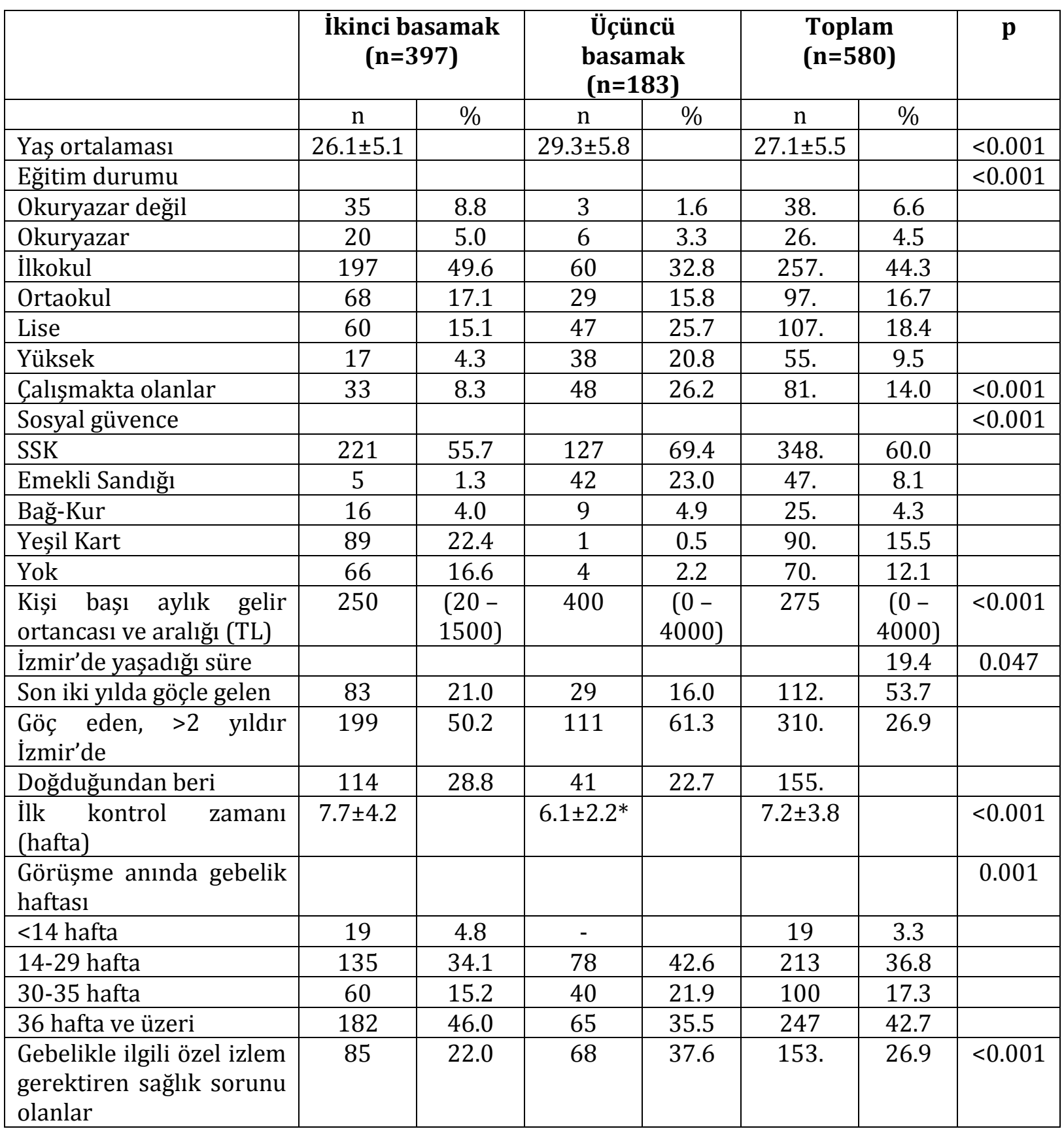

* Üniversitede görüşülen gebelerden en az 15'i tüp bebektir ve ilk kontrol zamanlarının ortalaması $4.7 \pm 2.0$ haftayken diğerlerinin ilk izlemleri ortalama $6.2 \pm 2.2$ haftalıkken yapılmıștır $(\mathrm{p}=0.005)$. 
Tablo 2. Gebelik testi, ilk izlem yeri, aile hekimi tarafından gebeliğin tespiti ve izlenme oranları $(\mathrm{n}=580)$

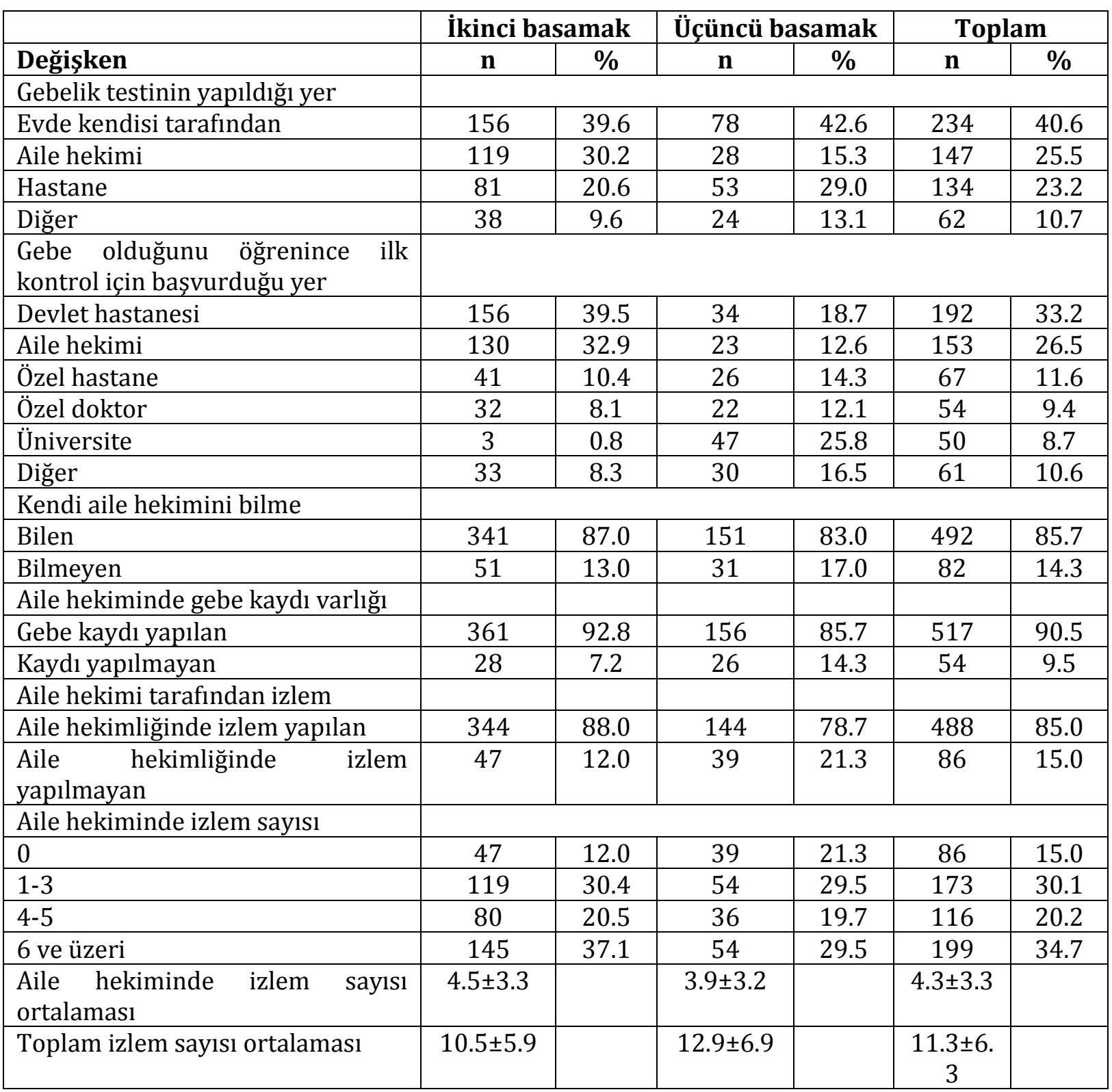

Aile hekimliğinde kaydı olmayanların yaş ortalaması $29.3 \pm 6.1$, olanlarınsa $\quad 26.9 \pm 5.4^{\prime}$ tür $\quad(\mathrm{t}=-3.029$, $\mathrm{p}=0.003)$. Eğitim düzeyi ve sosyal güvenceye göre aile hekiminde gebe olarak kayıtlı olma oranı anlamlı farklılık göstermektedir $(\mathrm{p}=0.014$ ve 0.001). Okuryazar değil, okuryazar ve yükseköğrenim olanların aile hekimine kayıtlı olma oranı (sırasıyla $\% 89.2$, \%84.6, \%77.8), ilkokul, ortaokul ve lise mezunlarından daha düşüktür (sırasıyla \%93.6, \%90.6, \%91.6). Sosyal güvencesi SSK ve Yeşilkart olanların ve güvencesi olmayanların sirasiyla \%93.0, \%91.0, \%91.4'ünün gebeliği aile hekiminde kayıtlıyken Emekli Sandığı ve BağKur'luların sirasıyla $\% 74.5$ ve \%83.3'ü kayıtlıdır. Aile hekimi tarafından kaydı yapılan gebelerin ilk kaydolma zamanı, aile hekiminin gebelikten haberdar olma şekli, izlemin kimin tarafından yapıldığı, evde izlem, izleme çağrılma özelliklerine göre dağılımı Tablo 3'te sunulmaktadır. 
Tablo 3. Aile hekimi tarafından kaydı yapılan gebelerin ilk kaydolma zamanı, aile hekiminin gebelikten haberdar olma yolu, izlemin özellikleri

\begin{tabular}{|c|c|c|c|c|c|c|}
\hline \multirow[b]{2}{*}{ Değişken } & \multicolumn{2}{|c|}{$\begin{array}{c}\text { İkinci } \\
\text { basamak }\end{array}$} & \multicolumn{2}{|c|}{$\begin{array}{l}\text { Üçüncü } \\
\text { basamak }\end{array}$} & \multicolumn{2}{|c|}{ Toplam } \\
\hline & $\mathbf{n}$ & $\%$ & $\mathbf{n}$ & $\%$ & $\%$ & $\mathbf{n}$ \\
\hline \multicolumn{7}{|l|}{$\begin{array}{l}\text { Aile hekimi tarafından tespiti yapılan } \\
\text { gebelerin }(\mathrm{n}=516) \text {; }\end{array}$} \\
\hline İlk tespit zamanı ortalaması (ay) & $2.8 \pm 1.7$ & & $2.7 \pm 1.7$ & & $2.8 \pm 1.7$ & \\
\hline \multicolumn{7}{|l|}{ İlk tespit zamanının dağılımı } \\
\hline Zamanında (14 hafta ve altı) & 236 & 68.2 & 106 & 71.1 & 342 & 69.1 \\
\hline Geç tespit & 110 & 31.8 & 43 & 28.8 & 153 & 30.9 \\
\hline 15-17 hafta & 38 & 11.0 & 16 & 10.7 & 54 & 10.9 \\
\hline $\begin{array}{l}18 \text { hafta ve üzeri (İkinci izlem zamanı ve } \\
\text { daha sonrası) }\end{array}$ & 72 & 20.8 & 27 & 18.1 & 99 & 20.0 \\
\hline \multicolumn{7}{|l|}{$\begin{array}{l}\text { Aile hekiminin gebelikten haberdar olma } \\
\text { yolu }\end{array}$} \\
\hline Gebelik nedeniyle kendisi bașvurdu* & 340 & 95.8 & 144 & 92.9 & 484 & 94.9 \\
\hline $\begin{array}{l}\text { Gebeliğini öğrenince kendisi kaydolmaya } \\
\text { gitti (izlemler, așı vb. için) }\end{array}$ & 198 & 64.9 & 88 & 61.1 & 286 & 63.7 \\
\hline Gebelik testi nedeniyle gittiğinde & 58 & 19.4 & 22 & 16.0 & 82 & 18.3 \\
\hline Tetanoz aşısı olmak için gittiğinde & 41 & 13.5 & 23 & 16.0 & 64 & 14.3 \\
\hline Gebelik ilacı yazdırmaya gittiğinde & 5 & 1.6 & 6 & 4.1 & 11 & 2.3 \\
\hline $\begin{array}{l}\text { Gebelikle ilgili sağlık sorunu/ tetkik için } \\
\text { gittiğinde }\end{array}$ & 1 & 0.3 & 2 & 1.4 & 3 & 0.7 \\
\hline Hekiminin yönlendirmesi & 1 & 0.3 & 2 & 1.4 & 3 & 0.7 \\
\hline Başka nedenle bașvurduğunda & 9 & 2.5 & 3 & 1.9 & 12 & 2.4 \\
\hline Ebenin ev ziyareti/ telefonla çağırması & 3 & 0.8 & 3 & 1.9 & 6 & 1.2 \\
\hline Tașınma sonrası kaydını getirdiğinde & 3 & 0.8 & 3 & 1.9 & 6 & 1.2 \\
\hline Diğer & - & & 2 & 1.3 & 2 & 0.4 \\
\hline \multicolumn{7}{|l|}{ Ebe ev ziyaretine geldi mi? } \\
\hline Evet & 9 & 2.6 & 6 & 3.8 & 15 & 2.9 \\
\hline Hayır & 343 & 97.4 & 154 & 96.3 & 497 & 97.1 \\
\hline \multicolumn{7}{|l|}{$\begin{array}{l}\text { Ebe tarafından düzenli olarak izleme } \\
\text { çağrılıyor mu? }\end{array}$} \\
\hline Evet & 276 & 78.9 & 115 & 71.9 & 391 & 76.7 \\
\hline Hayır & 74 & 21.1 & 45 & 28.1 & 119 & 23.3 \\
\hline \multicolumn{7}{|l|}{$\begin{array}{l}\text { Aile hekimi tarafından izlemi yaplan } \\
\text { gebelerin }(n=488) \text {; }\end{array}$} \\
\hline \multicolumn{7}{|l|}{ İzlemi yapan kişi } \\
\hline Ebe & 118 & 44.4 & 83 & 56.8 & 201 & 48.8 \\
\hline Aile hekimi & 88 & 33.1 & 22 & 15.1 & 110 & 26.7 \\
\hline Hem ebe hem aile hekimi & 60 & 22.5 & 41 & 28.1 & 101 & 24.5 \\
\hline
\end{tabular}

* Gebeliği nedeniyle kendisi başvuran 484 kişiden 449'unun alt başlıklara dağılımının verilebilmesinin nedeni, kendisinin hangi nedenle başvurduğunun araştırmanın ilk iki gününde sorgulanmamasıdır. Herhangi bir cevaplanmama yanlılığı bulunmamaktadır; formda yapılan değişiklikle üçüncü günden itibaren görüşülen tüm gebelere sorulmuştur.

Başka çocuğu olan ve bir önceki gebeliklerinde de İzmir'de yaşayan 226 gebenin 207'sinin (\%91.6) önceki Türkiye Halk Sağlığı Dergisi 2011;9(1) gebeliklerinde sağlık ocağı tarafından 
izlendiği saptandı. Önceki gebeliğinde ebesi tarafindan evde ziyaret edilenlerin oranı ise \%43.7'ydi $(n=83)$. Bu iki değişken, şimdiki gebelikleriyle karşılaştırıldığında aile hekimi tarafindan izlenme oranının, geçmişte sağlık ocağı tarafından izlenme oranından anlamlı olarak farklı olmadığı, ancak ebenin ev ziyareti oranları arasında anlamlı fark olduğu saptandı (McNemar $\mathrm{p}$ sirasiyla 0.200 ve $<0.001$ ). Önceki gebeliğinde sağlık ocağı ebesi tarafından ev ziyareti yapılma oranı, sosyal güvenceye göre anlamlı fark göstermekteydi $(\mathrm{p}<0.001)$ : Emekli sandığı mensubu olanların \%62.5'u, SSK'llların \%89.4'ü, Yeșil-Kartı olanların ve güvencesi olmayanların \%90.7'si ve Bă̆Kurluların \%100'ü önceki gebeliklerinde sağlık ocağı tarafından evde izlenmişti. Gebelik nedeniyle aile hekimine kendisi başvuranlar arasında yapılan karşılaştırmalara göre gebelik testi nedeniyle gidenlerin ortalama tespit zamanı 1.7 \pm 1.1 ay, gebeliğini öğrenince kendisi kaydolmaya gidenlerin $2.6 \pm 1.6$ ay, tetanoz aşısı için gidenlerin ise ortalama tespit zamanı $4.8 \pm 0.7$ ay bulunmuştur. Her üç ortalama arasinda anlamlı fark bulunmaktadır $(\mathrm{p}<0.001)$.Gebelerin 421'i (\%74.3) bu gebeliklerinde tetanoza karşı aşılanmış, 33'ü (\%5.8) aşlanmamış, 113'ünün (\%19.9) aşılanma zamanı gelmemişti. Aşılananların 402'si (\%95.5) aile hekiminde aşılanmıştı. Geçmişte yapılan aşıları da göz önünde bulundurulduğunda, bağışıklama durumu değerlendirilebilen 419 gebenin 380'i (\%90.7) tam aşıll, 20'si (\%4.8) eksik aşılı, 18'i (\%4.3) zamanı gelmemiş ve sadece biri (\%0.2) hiç aşısızd. Tek değişkenli analizlere göre ikinci basamakta izlenen gebelerin \%88.0'i aile hekimi tarafından izlenirken üçüncü basamaktakilerin \%78.7'si izlenmekteydi $(p=0.004)$. Gebelik haftasına göre düzeltme yapınca aslında kuruma göre aile hekimi tarafından izlenme oranının değişmediği, iki kurum arasında gözlenen farkın, üçüncü basamakta izlenenlerin gebelik haftası ortalamasının daha düşük $(p=0.004)$ olmasına bağlı olduğu anlaşıldı. Hem tek değișkenli, hem de gebelik haftasına göre düzeltilmiş analizlerde, aile hekimi tarafından izlenme oranının gebenin yaș, İzmir'de yaşadığı yer (metropol ilçeler/ metropol dişı), Mayıs 2007'den sonra farklı ilçeye taşınma, çocuğun sırası (ilk/ diğer), ilk kontrol haftası, anketin yapıldığı mekan (gebe izlem polikliniği/ doğum sonrası servis) özelliklerine göre değișmediği saptand $1(p>0.05)$. Aile hekimi tarafından izlenme oranını etkileyen değişkenler, Tablo 4'te analiz sonuçlarıyla sunulmaktadır. En düşük ve en yüksek eğitim düzeyine sahip olan gebelerde aile hekimi tarafından izlenme oranı en düşük, orta eğitim düzeylerinde ise izlem oranları daha yüksektir (Şekil 1).

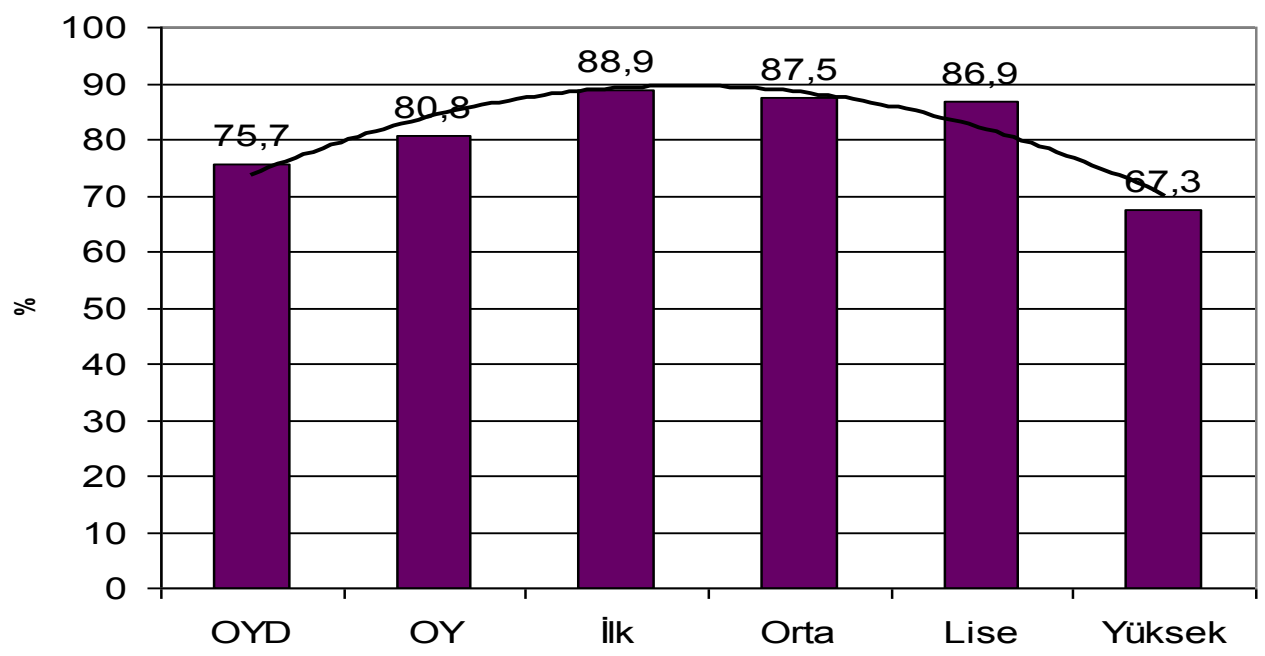

Şekil 1. Gebenin eğitim durumuna göre aile hekimliğinde izlenme oranı 
Tablo 4. Gebeliği en az 14 haftalık olan kadınların aile hekimi tarafından en az bir kez izlenme durumunu etkileyen etmenler

\begin{tabular}{|c|c|c|c|c|c|}
\hline & \multicolumn{4}{|c|}{ Aile hekimi tarafindan } & \multirow{3}{*}{$\mathbf{p}$} \\
\hline & \multicolumn{2}{|c|}{$\begin{array}{l}\text { İzlenen } \\
(n=466)\end{array}$} & \multicolumn{2}{|c|}{$\begin{array}{l}\text { izlenmeyen } \\
(n=62)\end{array}$} & \\
\hline & $\mathbf{n}$ & $\%$ & $\mathrm{n}$ & $\%$ & \\
\hline Eğitim durumu & & & & & 0.041 \\
\hline Okuryazar değil & 25 & 80.6 & 6 & 19.4 & \\
\hline Okuryazar & 21 & 87.5 & 3 & 12.5 & \\
\hline İlkokul & 211 & 90.2 & 23 & 9.8 & \\
\hline Ortaokul & 81 & 89.0 & 10 & 11.0 & \\
\hline Lise & 91 & 91.9 & 8 & 8.1 & \\
\hline Yüksek & 37 & 75.5 & 12 & 24.5 & \\
\hline Çalıșma durumu & & & & & 0.014 \\
\hline Çalıșıyor & 59 & 79.7 & 15 & 20.3 & \\
\hline Çalışmiyor & 407 & 89.6 & 47 & 10.4 & \\
\hline Sosyal güvence & & & & & 0.006 \\
\hline SSK & 288 & 91.1 & 28 & 8.9 & \\
\hline Emekli Sandığı & 30 & 71.4 & 12 & 28.6 & \\
\hline Bağ-Kur & 16 & 84.2 & 3 & 15.8 & \\
\hline Yeșil Kart & 75 & 87.2 & 11 & 12.8 & \\
\hline Yok & 57 & 87.7 & 8 & 12.3 & \\
\hline $\begin{array}{l}\text { Hanede kişi başına düşen aylık } \\
\text { gelir (TL) }\end{array}$ & & & & & $<0.001$ \\
\hline$<200 \mathrm{TL}$ & 145 & 93.5 & 10 & 6.5 & \\
\hline $200-399 \mathrm{TL}$ & 175 & 89.7 & 20 & 10.3 & \\
\hline 400-599 TL & 76 & 89.4 & 9 & 10.6 & \\
\hline 600 TL ve üzeri & 53 & 72.6 & 20 & 27.4 & \\
\hline İzmir'de yaşadığı süre & & & & & 0.037 \\
\hline Son iki yılda göçle gelen & 83 & 82.2 & 18 & 17.8 & \\
\hline$>2$ yıldır İzmir'de & 380 & 89.6 & 44 & 10.4 & \\
\hline Görüşme anında gebelik haftası** & & & & & $<0.001$ \\
\hline$<18$ hafta & 35 & 79.5 & 9 & 20.5 & \\
\hline 18-29 hafta & 112 & 80.0 & 28 & 20.0 & \\
\hline 30-35 hafta & 94 & 94.0 & 6 & 6.0 & \\
\hline 36 hafta ve üzeri & 225 & 92.2 & 19 & 7.8 & \\
\hline $\begin{array}{l}\text { Gebelikle ilgili özel izlem } \\
\text { gerektiren sağlık sorunu }\end{array}$ & & & & & 0.172 \\
\hline Var & 123 & 26.6 & 21 & 35.0 & \\
\hline Yok & 339 & 73.4 & 39 & 65.0 & \\
\hline
\end{tabular}

** Düzeltme yapılan değişken olduğu için tek değișkenli lojistik regresyon sonuçları sunulmaktadır.

Aile hekimi tarafından izlem sayılarının yeterliliği, gebelik haftasına göre değerlendirilmiștir ve Tablo 5'te sunulmaktadır. 
Tablo 5. Gebelerin gestasyon haftalarına göre aile hekimliğinde izlenme durumları

\begin{tabular}{|l|c|c|c|c|c|c|c|}
\hline \multirow{2}{*}{ Gebelik haftası } & \multicolumn{2}{|c|}{ Tam izlenenler } & \multicolumn{2}{|c|}{ Eksik izlenenler } & \multicolumn{2}{c|}{ Hiç izlenmeyen } & Toplam \\
\cline { 2 - 7 } & $\mathbf{n}$ & $\mathbf{\%}$ & $\mathbf{n}$ & $\mathbf{\%}$ & $\mathbf{n}$ & $\mathbf{\%}$ & $\mathbf{n}$ \\
\hline$<18$ hafta & 56 & 62.9 & - & & 33 & 37.1 & 89 \\
\hline 18-29 hafta & 98 & 70.0 & 14 & 10.0 & 28 & 20.0 & 140 \\
\hline 30-35 hafta & 77 & 77.0 & 17 & 17.0 & 6 & 6.0 & 100 \\
\hline 36 hafta ve üzeri & 182 & 74.6 & 43 & 17.6 & 19 & 7.8 & 244 \\
\hline Toplam & 413 & 72.1 & 74 & 12.9 & 86 & 15.0 & 573 \\
\hline
\end{tabular}

$\chi^{2}=64.658, \mathrm{p}<0.001$

\section{Tartışma}

İzmir'de aile hekimliği modeline geçildikten yaklaşık bir buçuk yıl sonra iki hastanede yürütülen bu araştırmada, gebelerin \%14'ünün aile hekimlerini bilmediği, \%10'unun aile hekimlerinde kaydının bulunmadığı ve \%15'inin bu hekimlerce izlenmediği ortaya konmuștur. Kadınların gebe olduğunu öğrenince ilk kontrol için başvurduğu yer aile hekimi değil, devlet hastaneleridir.

İzmir'de aile hekimliğine geçilmeden önce 224 sayılı yasanın gereği olarak nüfus tabanlı bir birinci basamak sistemi yürütülmekteydi. Sağlık ocaklarının temel kurum olduğu bu sistemde her yil ebeler tarafından bölgedeki evler dolaşılarak nüfus tespiti yapılmaktaydı. Bu nüfus tabanlı model değiştirilmeden önce, aile hekimlerine dağıtılacak nüfusun iyi belirlenebilmesi için ebeler rutin işlerini aksatacak kadar yoğun biçimde ev halkı tespit fişlerini güncellemek için dolaşmışlar ve TC kimlik numaraları toplamışlardır. Bunun yanı sıra, yeni düzenlenmiş olan Adrese Dayalı Nüfus Kayıt Sistemi verileri sağlık müdürlüğü aracılığıyla ebelere gönderilmiş, tespit çift kontrollü olarak tamamlanmıștır. ${ }^{6} \quad$ 2000-2007 Ylları arasında Nesanır ve Erkman'ın Sağlık Bakanlı̆̆ı'ndan aldıkları verileri değerlendirdikleri araştırmalarında İzmir'de gebe başına ortalama izlem sayısının 2004, 2005 ve 2006 yillarında sırasıyla 5, 5.4 ve 5.4 olduğu bildirilmiştir. ${ }^{11}$ Sağlık Ocağı döneminde İzmir Sağlık Müdürlügü'nün verilerine ulaşllamamakla birlikte, Kılıç ve arkadaşlarının Narlıdere Sağlık Grup Başkanlığı'nda hizmet değerlendirilmesi yaptıkları yöneylem araştırmasında; 1999 yılında sağlık ocaklarının \%70,6'sında nüfusun tamamının gezici ebe hizmeti alırken 2002'de nüfusun tamamının bu hizmeti aldığı ve gebe başına ortalama izlem sayısının aynı yıllar içinde 5.0'dan 5.8'e çıktığı bildirilmektedir.12

Nüfus tespitinin bu kadar iyi yapıldığı bir dönemden sadece bir buçuk yıl sonra tespitin \%10 azalması, dikkatle değerlendirilmesi gereken bir sonuçtur. Aynı zamanda sağlı hizmetlerinde basamaklar arasında eşgüdümün olmadığını da göstermektedir. Çünkü sağllk kurumlarına başvuran gebelerin \%10'unun kaydı yoktur. Ülkenin tamamında aile hekimliğine geçilmesiyle birlikte aile hekimine kayıtlı kişi sayısının 68 milyon olup 4 milyon kişinin henüz kaydedilememiş olması, yeni geçilen illerde daha uygulamanın başında tespitin yetersiz olması nedeniyle sorunun daha büyük boyutta olacağını göstermektedir. ${ }^{13}$

Tespit edilmeyen gebelerin çoğunluğunu iyi eğitimliler ve sosyal güvencesi olanlar oluşturmakla birlikte $\% 15$ kadarını hiçbir formal eğitimi olmayanlar oluşturmaktadır. Aile hekimliğinin nüfus tabanlı değil, liste tabanlı bir model olması, kayıtların iyi olduğu bir dönemde bile kayıtsızların oranının bu kadar yüksek olması, hiçbir formal eğitimi ve sigortası olmayan bir kesimin birinci basamak sağlık sisteminin dıșında kalabileceğini göstermektedir. TNSA 2008 raporunda, düşük gelir ve eğitim seviyeleri Türkiye'de doğum öncesi bakımın önündeki önemli 
engeller olarak bildirilmiştir. ${ }^{2}$ Türkiye'de bebek ve anne ölüm hızlarının kendi gelir seviyesindeki Ekonomik İşbirliği ve Kalkınma Teşkilatı (OECD) ülkelerinden yüksek olduğu da göz önünde bulundurulursa, kayıt dışında kalma olasılığı olan bu gebelerin tespiti için ek önlemlerin alınması gerektiği açıktır. ${ }^{14}$ Gebe izlemlerinin anne ve bebek ölümlülügünü önlemede yeri önemlidir ve özellikle sosyoekonomik düzeyi düşük gruplarda gebelerin ilk tespit zamanının ve izlem sayısının bebeğin sağlığına etkileri gösterilmiştir. ${ }^{10,15}$

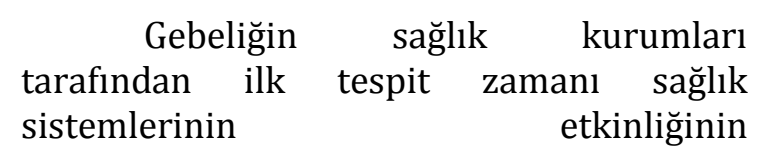
değerlendirmesinde en önemli kriterlerden kabul edilmektedir.2,16,17 Türkiye'de ilk ziyarette ortanca gebelik süresi 2.2 aydır. ${ }^{6}$ $\mathrm{Bu}$ çalışmada gebelik tespit zamanının Türkiye ortalamasından daha iyi olduğu ve çoğunun birinci trimesterde izlem yaptırmaya başladığı görülmektedir. Özellikle üniversiteden hizmet alan gebelerin ilk izlem tarihi oldukça erken dönemdedir. Üniversite hastanesinden hizmet alan gebelerin eğitim ve gelir seviyelerinin anlamlı olarak daha yüksek olması ve tüp bebek tedavisi görenlerin izlemlerinin de aynı kurumda ve çok erken evrede başlaması bu sonuca katkıda bulunmuş olabilir. Başka bir araştırmada da üniversite hastanesinden hizmet alan gebelerin eğitim seviyeleri yüksek saptanmıştır. ${ }^{18} \mathrm{Bu}$ çalışmada gebelik tespit zamanının görece iyi olmasının nedeni, ikinci ve üçüncü basamakta yapılan tespitlerin de hesaba katılmasıdır. Birinci basamak özelinde incelendiğinde, gebelerin sadece \%69'u birinci trimesterde aile hekimine kaydolmaktadır. Gebelerin çoğu ilk izlem için aile hekimlerine değil öncelikle devlet hastanelerine başvurmuşlardır. Aile hekimine kaydın nasıl gerçekleştiği incelendiğinde gebelerin çoğunun (\%95) aile hekimlerine kendileri başvurarak kayıt yaptırdıkları, aile hekimi tarafından bir saptamanın yapılmadığı görülmektedir. Kayıt yaptıranların \%14'ünün ilk kaydının tetanoz aşısı olmak için gittiğinde, dolayısıyla 18. haftadan sonra, geç bir tarihte kaydolması düşündürücüdür.
Gebenin en iyi birinci basamaktan alabileceği sağlığını geliştirici, koruyucu önlemler hakkında bilgi alması gecikmekte ve ilk tespitte doldurulması gereken Risk Değerlendirme Formu için geç kalınmış olmaktadır. Tespitlerin gecikmesinin bir nedeni, aile hekimliğine geçilen illerde 1549 yaş kadın izlemlerinin azalması olabilir. ${ }^{11}$ Tespitler geciktiği için de aile hekimlerinde izlem düzeyi ancak 30. haftadan sonraki gebeliklerde düzelmektedir.

Gebelerin \%97.1'ine ev ziyareti yapılmamıștır ve \%23.3'ü telefonla da izleme çağrılmamıștır. Bu durum izlenen gebelerin çoğunun izlemler konusunda farkındalığının olduğunu, kendi ve bebeklerinin sağlığı için sorumluluk almaya niyetli ve eğitimli olduklarını göstermektedir. Önceki gebeliğinde evde ziyaret edilen gebe sayısının yüksek olması, sağlık ocağ sisteminde bu kadınların gebe izlemlerini birinci basamakta yaptırma alıșkanlığını edindiğini düșündürmektedir. Araştırma grubunun büyük çoğunluğunun aile hekimlerini hala sağlık ocağı olarak adlandırması bunu desteklemektedir. Emekli sandığı mensubu olanların \%62.5’u, SSK'lıların \%89.4'ü, Yeşil-Kartı olanların ve güvencesi olmayanların \%90.7'si ve BağKurluların \%100'ünün önceki gebeliklerinde sağlık ocağı tarafından evde izlenmiş olması, sağlık ocaklarının özellikle gereksinimi olanlara ev ziyaretlerini gerçekleştirdiğine işaret etmektedir. Koruyucu sağlık hizmetlerinin verilebilmesi için bölgede yaşayan nüfusun düzenli olarak tespiti önemlidir. Sağlık Ocakları ve Ana Çocuk Sağlığı ve Aile Planlaması (AÇSAP) Merkezleri tarafından yapılması gereken "gezici hizmetler" 224 Sayılı Sağlık Hizmetlerinin Sosyalleştirilmesi Hakkında Kanun kapsamında hazırlanmış olan Sağlık Hizmetlerinin Yürütülmesi Hakkında Yönerge'de detaylı olarak anlatılmıştır. ${ }^{19}$ Aile hekimliği yönetmeliğinde de ev ziyaretleri tanımlanmıştır. Buna rağmen uygulanmadığı görülmektedir. Kadınların eğitim seviyesinin ve statüsünün istenen düzeyde olmadığı, geleneksel uygulamaların yaygin olduğu Türkiye'de, ev ziyaretleri hem birinci basamak sağlık hizmetlerinin kadına tanitılmasında, hem de gebe ve bebek izlemlerinin nitelik ve niceliğinin 
arttırılmasında önem tașımaktadır.2,20 Evde gebe ve bebek izlemi sadece gelişmekte olan ülkelerde değil, anne ve bebek ölümlülügünü azaltmada, anne ve bebeğin ruh ve beden sağlığına olan önemli katkıları nedeniyle birçok gelişmiş ülkede de rutin olarak sürdürülmektedir. Literatürde evde ziyaretin izlem alma oranını arttırdığının yanı sıra, anne ve bebekle ilgili koruyucu davranışları da olumlu etkilediği bildirmektedir., ${ }^{4,5,21}$ Sağlıkta Dönüşüm öncesi dönemde sağlık ocağı hizmet kullanımının değerlendirildiği bir araştırmada ev ziyaretlerinin reform süreciyle birlikte azalmakta olduğu, sağlık kuruluşları tarafından evlerinde ziyaret edilme oranının \%33.7'den \%25.1'e düştüğü ve birinci basamaktan koruyucu sağlık hizmeti alma oranının benzer şekilde düştüğü bildirilmiștir. $^{22}$

Aile hekimleri tarafindan izlenmeyen gebeler ya formal eğitimi olmayan (\%44) ya da yükseköğrenim mezunu gebelerdir (\%32). Farklı ülkelerde yapılan araștırmalarda sosyoekonomik seviyesi daha düşük olan grupların ikinci, üçüncü basamak sağlık hizmetlerine erişiminin sorunlu olduğu ve birinci basamaktan daha fazla hizmet aldıkları ortaya konmuştur.23-25 Ayrica son iki yılda İzmir'e göçle gelenlerin aile hekimi tarafından izlenme oranı anlamlı düzeyde daha düşüktür. Göç anne ve bebek sağlığı açısından önemli bir risk faktörüdür. Oysa 2004 yılında İzmir'de bir sağlık ocağı bölgesinde yürütülen bir araştırmada Doğu ve Güneydoğu Anadolu bölgesinden gelmiş göçmenlerin sağlık ocağını çok yoğun olarak kullandığ $\breve{l}_{1} \quad$ saptanmıştır. ${ }^{26}$ Artık gerçekleştirilmeyen ev ziyaretleri, kurumun tanınmasını geciktirmiş ve hizmetin alınmasının önünde engel oluşturarak önemli rol oynamış olabilir. Ev ziyaretlerinin yok denecek kadar az olması, göç etmiş, kentteki sağlık hizmetlerinden haberi olmayan, eğitim ve gelir seviyesi iyi olmayan kadınların DÖB hizmetlerinden yararlanma durumunu olumsuz etkilemiștir.

Gebeler aile sağlığı birimi tarafından ortalama dört kez izlenirken, toplam izlem ortalamaları 11'dir. Edirne'de 2005 yılında ortalama 11 olan gebe izlem sayıs 2007 yılında 4.6'ya düşmüştür. Benzer durum Denizli ve Isparta için de saptanmıştır. 2007 yılında Düzce'de gebe başına düşen izlem sayısı 3.7 Adıyaman'da 3.8 olarak saptanmıştır. ${ }^{11} \mathrm{Bu}$ araştırmada da gebeler aile hekimleri tarafindan performans kriteri olan dört kez izlenmişlerdir. Fakat gebelerin çoğunluğu tek izlem kaynağı olarak aile hekimlerini kullanmamakta, farklı kaynaklardan da izlem yaptırmaktadır. Bu araştırmada sorgulanmamakla birlikte, gebelerin ultrason yaptırma isteği ve aile hekimlerinde bu hizmetin olmaması, birinci basamakta ultrason hizmeti sunan AÇSAP sayısının azaltılmış olması bu durumu etkilemiș olabilir.6,27

Aile hekimliği pilot kanununda gebe izlemleri hekimin asli işlerinden olarak belirtilmiş, aile sağlığı elemanına ise sadece yardımcı bir rol tanımlanmıştır. Oysa çalışma grubumuzda izlem için aile hekimlerine başvuran gebelerin \%49'u sadece ebelerden hizmet almaktadır. $\mathrm{Bu}$ durum da gebelerin farklı izlem kaynaklarına yönelmesini açılayabilir. Sağlık Emekçileri Sendikası'nın (SES) 2006'da yayınladığı Düzce ve Eskişehir aile hekimliği uygulamalarıyla ilgili raporunda da gebe tespitlerinin yapılmadığ izlemlerin sadece aile sağlı̆̆ elemanı tarafından yapıldığı belirtilmektedir. ${ }^{28}$ Onbir pilot il içinde aile sağlığı elemanı kadrolarındaki sözleşmeli personel oranı \%49 ile en düşük İzmir'de saptanmıștır. Birinci basamakta çalışan ebe-hemşire sayısında artış olmazken hekim sayısı önemli bir oranda artmıștır. ${ }^{14}$ Hekim sayısında artış olduğu halde hekimlerin gebe izlemlerine katılımında artış olmaması ve pilot kanunda temel rolü ev ziyaretleri ve sağlık eğitimiyle sınırlandırılan ebelerin, hala sağlık ocağı sisteminde olduğu gibi gebe ve bebek izlemlerini yalnız yapıyor olması, çelişkili bir durumdur.

Tüm Türkiye 2011'de aile hekimliği modeline geçecektir. Doğum öncesi bakımda TNSA 2008'de de vurgulanan bölgesel eşitsizlikler mevcuttur. Aile hekimliği sisteminde kırsalda tüm sağlık hizmeti ilköğretimde olduğu gibi taşımalı sisteme devredilmiştir. Haftada bir köye uğrayan aile hekimleri tarafından yürütülmesi 
beklenmektedir. $\quad \mathrm{Bu}$ da 2008 TNSA sonuçlarında 2003'e göre görece daha iyileşmiş olan kırsaldaki DÖB hizmetlerini olumsuz yönde etkileyebilir.

Doğumların nerdeyse tamamının hastanede gerçekleştiği İzmir'de her ne kadar sosyoekonomik açıdan tüm gebelere erişebilmek amaciyla hem Konak Doğumevi'nde (\%39 Yeşil kart ya da yok) ve Ege Üniversitesi Tıp Fakültesi'nde (\%23 Emekli Sandığı) yürütülse de alan araştırması olmaması nedeniyle hiçbir sağllk kurumuna başvuramayan gebeler araştırma dışında kalmıştır. Ayrıca İzmir'deki tüm sağlık kurumlarını da temsil etmemektedir. Anketin yapıldığı dönemdeki tüm gebelere ulaşılamamıştır. Araştırmanın bir diğer sinırlılığı da gebe izlem polikliniğinde görüşülenlerin henüz gebelikleri devam ettiği için görüşme sonrasında aile hekimi tarafindan tespitleri ya da izlemlerinin mümkün olmasıdır. Bunun getirebileceği yanlılığ kaldırmak için izlemler gebelik haftasına göre de değerlendirilmiştir. Bu çalışma izin alma sorunu nedeniyle alanda yürütülememiş ve bahsi geçen sınırlılıkları içermiştir. Gerçek durumun yansız olarak ortaya konabilmesi için alan araştırmaları yapılması gerekmektedir.

\section{Sonuç}

Bu araştırma, eğitim ve gelir seviyesi daha düşük olanların, göç edenlerin yani dezavantajlıların birinci basamakta DÖB hizmetlerinden yararlandığını ortaya koymuştur. Bununla birlikte sağlık hizmeti almakta olan gebelerin \%10'unun birinci basamakta kaydının olmaması, olan gebelerin de çoğunlukla sadece ebelerden hizmet alıyor olması ek önlemlere gereksinim olduğunu göstermektedir. Ev ziyaretleri arttırılmalıdır. Tetanoz aşısı, aile hekimi ile temas açısından kritik bir andır, ancak gebe tespiti böyle geç bir zamana kalmamalıdır. Herhangi bir şekilde ikinci ya da üçüncü basamaktan hizmet alan gebelerin aile hekimlerine bildirimi sağlanmalıdır. Aile hekimleri sadece başvuranlara hizmet vermektedir. Toplum Sağlığı Merkezleri belirli aralıklarla saha çalışmaları yapmalı ve gebe ve bebek tespitini daha iyi değerlendirmelidir. Görüşülen gebelerin yaklaşık beşte birinin son iki yılda İzmir'e göç edip yerleştiği göz önünde bulundurulduğunda, liste üzerinden hizmet sunan aile hekimliği modelinde göçle gelen ve birinci basamak sağlık hizmetini nasıl kullanacağını bilmeyen kesime nasıl ulaşılacağı konusunda bir yöntem belirlenmesi gerekmektedir. Gebe izlemi yapılan tüm hastanelerden aile sağlığı ve toplum sağlığı merkezlerine bilgi akışı sağlanmalıdır.

\section{Teșekkür}

Araștırmaya katılmayı kabul eden gebelere ve yeni doğum yapmış kadınlara duyarlılıklarından dolayı teşekkürlerimizi sunariz.

\section{Kaynaklar}

1-DSÖ. Maternal mortality. Fact sheet $N^{\circ} 348$ November 2010. Erişim yeri: http://www.who.int/mediacentre/facts heets/fs348/en/index.html Erişim tarihi: $30 / 03 / 2011$

2- Hacettepe Üniversitesi Nüfus Etütleri Enstitüsü. Türkiye Nüfus ve Sağlık Araştırması, $2008 . \quad$ Hacettepe Üniversitesi Nüfus Etütleri Enstitüsü, Sağlık Bakanlığı Ana Çocuk Sağlığı ve Aile Planlaması Genel Müdürlüğü, Başbakanlık Devlet Planlama Teşkilatı Müsteşarlığı ve TÜBíTAK. Ankara, 2009

3-Tucker JS, Hall MH, Howie PW, Reid ME, Barbour RS, Florey C Du V, Mcllwaine GM. Should obstetricians see women with normal pregnancies? A multicentre randomised controlled trial of routine antenatal care by general practitioners and midwives compared with shared care led by obstetricians. BMJ 1996; 312 : 554

4- Issel LM, Forrestal SG, Slaughter J, Wiencrot A, Handler AJ A Review of Prenatal Home-Visiting Effectiveness for Improving Birth Outcomes Obstet Gynecol Neonatal Nurs. 2011 Mar;40(2):157-165. 
5-Kemp L, Harris E, McMahon C, Matthey S, Vimpani G, Anderson T, Schmied V, Aslam H, Zapart S. Child and family outcomes of a long-term nurse home visitation programme: a randomised controlled trial. Arch Dis Child. 2011 Mar 23. doi:10.1136/adc.2010.196279

6-TTB Halk Sağlığı Kolu. 19. Gezici eğitim Semineri 2007-Aile hekimliği. Toplum ve Hekim 2010; 25: 56-71.

7- 5258 sayılı Aile Hekimliği Pilot Uygulaması Hakkında Kanun. Resmi Gazete 9.12.2004: Sayı: 25665. Erişim yeri:http://www.ttb.org.tr/mevzuat/ind ex.php?option $=$ com_content\&task=categ ory\&sectionid=1\&id=4\&Itemid=31.

Erişim tarihi 15 Aralık 2010.

8- Aile Hekimliği Pilot Uygulaması Kapsamında Sağlık Bakanlığınca Çalıştırılan Personele Yapılacak Ödemeler Ve Sözleşme Şartları Hakkında Yönetmelik Resmi Gazete 12.08.2005: 25904. Erişim yeri: http://www.saglik.gov.tr/TR/belge/17286/aile-hekimligi-pilot-uygulamasikapsaminda-saglik-bakan-.html. Erişim tarihi 15 Aralık 2010.

9-Sağlık Bakanlığı. Ana Çocuk Sağlı̆̆ı ve Aile Planlaması Genel Müdürlüğü Doğum Öncesi Bakım İzlem Protokolü Genelgesi 19.02.2008. Erişim yeri: http://www.saglik.gov.tr/TR/belge/16077/dogum-oncesi-bakim-izlem protokolu-genelgesi-2008--13.html. Erişim tarihi 15 Aralık 2010.

10-Alexander GR, Kotelchuck M. Assessing the role and effectiveness of prenatal care: history, challenges, and directions for future research. Public Health Rep 2001;116: 306-16.

11-Nesanır N, Erkman N. Aile hekimliği uygulamasına geçen ilk 11 ilin sağlı göstergeleri üzerinden bu sürece bir bakış. TAF Prev Med Bull 2010; 9: 493504.

12- Kılıç B, Günay T, Demiral Y, Ünal B, Keskinoğlu P, Konakçı S, Şahin A, Koç S, Kıran S, Civaner M. Narlıdere Eğitim Araştırma Bölgesi Sağlık Ocaklarında Yöneylem Araştırması (1999-2002) TSK
Koruyucu Hekimlik Bülteni, 2007: 6 (1) 77-90

13-Sağlık Bakanlığı. Sayın Bakanımız Prof. Dr. Recep Akdağ Kanal D "Doktorum" Programinın Konuğuydu 16.12.2010. Erişim yeri: http://www.saglik.gov.tr/TR/belge/111503/doktorum-programi 16122010.html Erişim tarihi: 21.12.2010.

14-OECD: OECD Reviews of Health Systems - Turkey, 2008. Erişim yeri: http://www.oecd.org/document/60/0,3 746,en_2649_34629_42235452_1_1_1_1, 00.html, Erişim tarihi 25 Kasım 2009

15-Dubay L, Joyce T, Kaestner R, Kenney GM. Changes in prenatal care timing and low birth weight by race and socioeconomic status: implications for the Medicaid expansions for pregnant women. Health Serv Res. 2001;36(2):373-98.

16-Deb P, Sosa-Rubi SG. Does onset or quality of prenatal care matter more for infant care? HEDG Working Paper 05/11, October 2005, Erişim yeri: http://www.york.ac.uk/res/herc/docum ents/wp/05_11.pdf Erişim tarihi 14 Aralık 2010.

17-Liu GG. Birth outcomes and the effectiveness of prenatal care. Health Services Research 1998; 32: 805-23.

18-Pirinççi E, Polat A, Kumru S, Köroğlu A. Bir üniversite hastanesinde doğum yapan kadınların doğum öncesi bakım alma durumu ve etkileyen faktörler. ADÜ Tıp Fakültesi Dergisi 2010;11:1-7.

19-224 Sayllı Sağlık Hizmetlerinin Sosyalleştirilmesi Hakkında Kanun. Resmi Gazete Tarihi 12.01.1961: 10705. Erişim yeri: http://www.saglik.gov.tr/TR/belge/1463/sayisi224--rg-tarihi12011961--rgsayisi10705-saglik-hiz-.html Erişim tarihi 24 Aralık 2010.

20-Kartal SB, Birler AG, Özkul D, Ünlüer S, Gürleyük S, Yamak A, Öztürk Y, Topuzoğlu AB. İstanbul'da gebe, lohusa, bebek ve çocuk izlemlerinin 
iyileştirilmesi: GEBLIZ. TAF Preventive Medicine Bulletin 2010; 9: 289-96.

21-Carroli G, Villar J, Piaggio G, KhanNeelofur D, Gülmezoglu M, Mugford M et al. WHO systematic review of randomised controlled trials of routine antenatal care. The Lancet 2001; Volume 357(9268): 1565-1570.

22-İlhan M, Tüzün H, Aycan S, Aksakal FN, Özkan S. Birinci basamak sağlık kuruluşuna başvuranların sağlık hizmeti kullanma özellikleri ve bazı sosyoekonomik belirteçlerle değişimi: sağllk reformu öncesi son saptamalar. Toplum Hekimliği Bülteni 2006; 25: 3341.

23-Balabanova D, Mc Kee M, Pomerlau J, Rose R, Haerfer C. Health service utilization in the Former Soviet Union: Evidence from eight countries. Health Serv Res 2004; 39: 1927-50.

24-Van Doorslaer E, Wargstaff A, Van Der Burg H, Christiansen T, De Graeve D, Duchesne I, et all. Equity in the delivery of health care in Europe and the US. J Health Econ 2000; 19: 553-83.
25-Droomers M, Westert GP. Do lower socioeconomic groups use more health services, because they suffer from more illnesses? Eur J Public Health 2004; 14: $311-3$.

26-Hassoy H, Çiçeklioğlu M. İzmir ili Gülyaka Sağlık Ocağ çocukların sağlık hizmeti kullanımları ve etkileyen faktörler. Toplum ve Hekim 2005; 20: 361-71.

27-Gülhan İ, Altunyurt S, Haciali G, Gülhan S. İzmir Konak 17 No.lu AÇSAP Merkezi bölgesindeki kadınların, gebelik takibi sirasinda ultrasonografi ile değerlendirilme sıklığı. Turkiye Klinikleri J Gynecol Obst 2007; 17: 356-360.

28-SES (Sağlık ve Sosyal Hizmet Emekçileri Sendikası) 2006. Düzce-Eskișehir Aile Hekimliği Gözlem- İnceleme Raporu. Erişim yeri: http://www.ses.org.tr/index.php?option $=$ com_content $\&$ view $=$ article $\& i d=144 \% 3$ Adce-eskeh-ae-heklglem-celemeraporu\&catid $=45 \% 3$ Araporlar\&Itemid $=$ 135 Erişim tarihi 15 Aralık 2010 